\title{
PENGEMBANGAN MULTIMEDIA INTERAKTIF PADA MATA PELAJARAN IPA MATERI MENDESKRIPSIKAN DAUR HIDUP HEWAN DI LINGKUNGAN SEKITAR SISWA KELAS IV SEKOLAH DASAR
}

\author{
Erwin Putera Permana \\ Universitas Nusantara PGRI Kediri - erwinp@unpkediri.ac.id \\ Desy Nourmavita \\ Universitas Nusantara PGRI Kediri - desynourmavita57@gmail.com
}

\begin{abstract}
This research is motivated by the observation in grade IV of elementary school of Natural Science subject (IPA) animal life cycle, because most students experience saturation in learning because the teacher still use conventional teaching method that is lecture. In addition, the source of student learning comes only from teachers and textbooks alone without any use of instructional media. Teachers do not pay attention to the explanations of teachers and students do not understand the material being taught. This research is a research development or research and development $(R \& D)$ adapted from the ADDIE development model. The stages are 5 stages: 1) Analysis (Analysis), Development (Design), Implementation (Implementation), and Evaluation (Evaluation). Validation is done by material experts, media experts, and learning practitioners. The results of this study are (1) Development of Interactive Multimedia Life Cycle Animals using professional adobe flash CS6 application with the method of ADDIE model development. (2) The teacher's response to this media is the optimism of teachers to achieve the learning objectives, as well as the students' response to this media is very positive, they are very fond of this media. (3) Interactive multimedia from the big aspect based on the percentage of the feasibility assessment in the category is very appropriate to be used as learning media of Natural Science for fourth grade students of elementary school. Based on the conclusions of the results of this study, namely: (1) For teachers, can use interactive multimedia to help students become more active and can create a fun classroom atmosphere. (2) For further research, make a broad try again, in order to produce learning media that can be used widely.
\end{abstract}

Keywords: Interactive Multimedia, Science, Animal Life Cycle.

\section{PENDAHULUAN}

Pembelajaran Ilmu Pengetahuan Alam (IPA) adalah pembelajaran yang sangat penting bagi siswa. Pentingnya pembelajaran IPA dikarenakan pembelajaran IPA berkaitan dengan lingkungan kehidupan sehari - hari. Bagi sebagian siswa pembelajaran IPA adalah pembelajaran yang kurang menarik. Hal ini dikarenakan pembelajaran IPA yang konvensional.

Menurut Susanto (2013: 165), salah satu masalah yang dihadapi dunia pendidikan saat ini adalah lemahnya pelaksanaan proses pembelajaran yang diterapkan oleh guru. Dimana dalam pelaksanaan proses pembelajaran, siswa hanya diarahkan pada kemampuan menghafal berbagai informasi tanpa ada tuntutan kepada siswa untuk memahami dan menerapkan informasi pada kehidupan sehari-hari.

Permasalahan yang dihadapi sekarang ini berasal dari guru, dimana dalam proses pembelajaran guru hanya menuntut siswa untuk menghafal tanpa adanya pemahaman dan penerapan dalam kegiatan siswa sehari-hari. Dapat dikatakan siswa hanya mampu mengafal tanpa menerapkan.

Senada dengan Susanto, Haryono (2013: 2), menyatakan bahwa, dengan melihat masalah pembelajaran IPA di lapangan, maka peserta 
didik tidak terbiasa menggunakan daya nalarnya, tetapi justru terbiasa dengan cara menghafal, hanya terpaku pada buku sumber serta terasa ada jurang pemisah antara pembelajaran di kelas dengan lingkungan kehidupan sehari-hari.

Berdasar pernyataan di atas dapat diuraikan bahwa dalam pembelajaran IPA siswa Menurut Haryono (2013: 2), pembelajaran IPA yang demikian sudah memenuhi harapan dari Kurikulum Tingkat Satuan Pendidikan (KTSP), yaitu pembelajaran hendaknya bersifat mendidik, mencerdaskan, membangkitkan aktivitas dan kreativitas anak, efektif, demokratis, menantang, menyenangkan, dan mengasyikkan.

Dengan pembelajaran yang bersifat sesuai dengan yang diuraiakan di atas akan menghasilkan siswa yang kreatif, aktif, dan cerdas. Siswa yang mampu mengaplikasikan teori-teori pembelajaran dalam kehidupan seharihari.

Keaktitifan siswa di dalam proses pembelajaran IPA merupakan inti dari pola belajar. Hal ini tercermin dari keaktifan siswa dalam mengaitkan konsep-konsep saat berdiskusi, siswa melakukan observasi dan siswa dapat mengkritisi suatu permasalahan yang muncul dalam lingkungan sekitar.

Menurut Susanto (2013: 170), pembelajaran IPA dilakukan dengan penyelidikan sederhana bukan hafalan konsep. Pembelajaran yang demikian dapat menumbuhkan sikap siswa dalam merumuskan masalah dan menarik kesimpulan, sehingga siswa mampu berpikir kritis melalui pembelajaran IPA.

Dari pemaparan di atas, dapat disimpulkan pembelajaran IPA ditekankan pada kemampuan berpikir kritis yang memberikan pengalaman langsung sehingga siswa dapat mengingat, mengidentifikasi, serta menerapkan pengetahuannya secara ilmiah. Oleh karena itu, guru harus berpedoman pada kurikulum untuk merencanakan pembelajaran.

Berdasarkan hasil observasi yang dilakukan di Sekolah Dasar, peneliti menemukan beberapa masalah yaitu bahan ajar yang dijadikan pengantar sumber belajar untuk siswa kelas IV, belum memberikan keterangan secara jelas mengenai tahapan perubahan bentuk tubuh hewan yang mengalami daur hidup dengan metamorfosis dan hewan yang mengalami daur hidup tanpa metamorfosis. Selain itu, materi hanya disajikan melalui gambar visual (grafis) ditekankan menggunakan daya nalarnya untuk berpikir kritis dalam menanggapi suatu permasalahan yang ada. Serta siswa juga harus bisa menerapkan atau mengaplikasikan materi yang telah dipelajari di kelas agar tidak ada jurang pemisah antara pembelajaran di kelas dengan lingkungan kehidupan sehari-hari.

semata yakni berupa media wallchart yang terdapat pada buku ajar. Oleh karena itu, dalam proses belajar mengajar, siswa perlu dilibatkan secara aktif guna meningkatkan pemahaman mereka terhadap materi yang diajarkan. Serta guru harus bisa membuat media pembelajaran yang bisa menarik minat siswa untuk aktif dalam proses belajar mengajar.

Dari permasalahan yang di uraikan di atas, perlu dikembangkan media pembelajaran yang tepat untuk membantu pembelajaran materi daur hidup hewan. Salah satu media yang tepat untuk dikembangkan adalah multimedia interakif. Penggunaan multimedia interaktif sebagai media pembelajaran materi daur hidup hewan sangat relevan. Hal ini dikarenakan pembelajaran IPA yang banyak memuat konsepkonsep abstrak yang membutuhkan pengkonkretan. Dengan menggunakan multimedia inetraktif, siswa akan lebih mudah memahami materi daur hidup hewan dalam proses belajar mengajar.

Berdasarkan latar belakang, maka rumusan masalah dalam penelitian ini yaitu : (1) bagaimanakah mengembangkan multimedia interaktif untuk mendeskripsikan daur hidup beberapa hewan di sekitar siswa kelas IV Sekolah Dasar? (2) bagaimanakah pendapat guru dan siswa setelah menggunakan multimedia interaktif hasil pengembangan untuk mendeskripsikan daur hidup beberapa hewan di sekitar siswa kelas IV Sekolah Dasar? Dan (3) bagaimanakah kelayakan produk multimedia interaktif untuk mendeskripsikan daur hidup beberapa hewan di lingkungan sekitar siswa kelas IV?

\section{METODE}

Pengembangan media pembelajaran $\mathrm{CD}$ interaktif ini menggunakan metode penelitian dan pengembangan (research and development). Menurut Sugiyono (2012: 297) "metode penelitian dan pengembangan (research and development) adalah metode penelitian yang digunakan untuk menghasilkan produk tertentu 
Senada dengan Sugiyono, Mulyatiningsih (2011: 145) "penelitian dan pengembangan (research and development) bertujuan untuk menghasilkan produk baru melalui proses pengembangan". Dari uraian di atas dapat di tarik simpulan bahwa penelitian dan pengembangan merupakan penelitian yang bertujuan untuk menghasilkan produk baru dan menguji keefektifan produk tersebut.

Menurut Mulyatiningsih (2011), ada 3 jenis penelitian dan pengembangan, yaitu Borg \& Gall, 4D, dan ADDIE. Dalam karya tulis penelitian dan pengembangan ini, pengembang menggunakan model ADDIE. ADDIE merupakan kepanjangan dari Analysis, Design, Development, Implementation, dan Evaluation. Model ini dikembangkan oleh Dick and Carry (Mulyatiningsih 2011: 185-186). Model ADDIE merupakan model yang disusun secara terprogram dengan urutan-urutan kegiatan yang sistematis dalam upaya pemecahan masalah belajar yang berkaitan dengan media belajar yang sesuai dengan kebutuhan dan karakteristik siswa.

Adapun Prosedur pengembangan model ADDIE terdiri dari lima tahapan, yaitu analyze (analisis), design (desain), development (pengembangan), implementation (implementasi), dan evaluation (evaluasi).

1. Tahap Analyze (Analisis)

a. Analisis kebutuhan yang meliputi kebutuhan dan karakteristik siswa yang akan menjadi sasaran pengguna CD interaktif

b. Analisis kompetensi dan intruksional yang meliputi analisis terhadap Standar Kompetensi (SK) dan Kompetensi Dasar yang akan dimuat dalam media ini. Standar Kompetensi yang akan dimuat adalah memahami daur hidup beragam jenis makhluk hidup. Analisis intruksional merupakan penjabaran Kompetensi Dasar (KD) yang telah dipilih pada tahap analisis kompetensi menjadi indikator

3. Tahap Pengembangan (Development)

a. Membuat Produk Media Pembelajaran Berupa CD Interaktif

Pada tahap ini produk media pembelajaran dibuat sesuai dengan format yang sudah ditentukan sebelumnya yaitu menggunakan aplikasi macromedia CS6.

b. Validasi Ahli Materi dan Ahli Media. Proses validasi dilakukan oleh ahli media dan ahli materi. Hasilnya berupa saran, pembelajaran yang memungkinkan untuk disajikan dalam CD interaktif.

2. Tahap design (desain)

Berdasarkan hasil analisis, tahap yang selanjutnya dilakukan adalah tahap desain atau perancangan produk yang meliputi tahap berikut :

a. Pembuatan Desain Media (storyboard) Storyboard merupakan gambaran media pembelajaran secara keseluruhan yang akan dimuat di dalam aplikasi. Storyboard berfungsi sebagai panduan seperti peta untuk memudahkan proses pembuatan media.

b. Menetapkan Materi

Pada tahap ini dikemukakan dasar pemilihan mata pelajaran ilmu pengetahuan alam mengenai daur hidup beberapa hewan. Ilmu pengetahuan alam dipilih karena sesuai dengan kompetensi penulis. Selain itu, terdapat kesulitan dalam hal kurangnya penggunaan media pembelajaran dan banyak guru yang masih menggunakan metode konvensional atau ceramah dalam mengajar ilmu pengetahuan alam.

c. Penyusunan Soal dan Jawaban

Soal dan pembahasan yang akan dimuat dalam media ini merupakan materi mengenai daur hidup beberapa hewan di lingkungan sekitar. Penyusunan materi, soal, dan pembahasan dalam media ini dibuat dari berbagai referensi.

d. Mengkaji Mata Pelajaran Sesuai dengan Kurikulum

Standar kompetensi memahami daur hidup beragam jenis makhluk hidup dengan Kompetensi Dasar mendeskripsikan daur hidup beberapa hewan di lingkungan sekitar, misalnya kecoa dan nyamuk, kupu-kupu, kucing dikaji sesuai dengan panduan kurikulum yang berlaku di sekolah saat ini.

komentar, dan masukan yang dapat digunakan sebagai dasar untuk melakukan analisis dan revisi terhadap media yang dikembangkan dan sebagai dasar untuk uji coba produk pada siswa.

4. Tahap Implementasi (Implementation) Tahap implementasi ini, produk akan diuji cobakan kepada 20 peserta didik dari SDN Krecek 3 dan 30 peserta didik dari SD Negeri Tunglur. Pada tahap ini 
juga dibagikan angket untuk mengukur dan mengetahui pendapat atau respon peserta didik mengenai media pembelajaran berupa CD Interaktif untuk pembelajaran Ilmu Pengetahuan Alam (IPA) materi daur hidup beberapa hewan di lingkungan sekitar. Bila diperlukan maka akan dilakukan revisi berdasarkan masukan dan saran dari peserta didik. Namun, dalam revisi ini akan dipertimbangkan masukan dan saran dari validator sebelumnya agar tidak bertentangan dengan perbaikanperbaikan sebelumnya.

5. Evaluasi (Evaluation)

Dari tahap uji coba diperoleh penilaian dan respon dari angket yang diberikan kepada guru dan siswa serta hasil tes yang diberikan kepada siswa. Angket dan hasil tes tersebut akan dianalisis untuk mengetahui efektivitas media tersebut. Hasil analisis ini digunakan sebagai acuan perlu tidaknya revisi produk tahap akhir.

\section{HASIL DAN PEMBAHASAN}

\section{Tahap Analisis (Analysis)}

a. Analisis kebutuhan dan karakteristik siswa

Penelitian ini berawal dari observasi ke sekolah SDN Krecek 3 khususnya di kelas IV pada mata pelajaran Ilmu Pengetahuan Alam (IPA) materi daur hidup hewan. Berdasarkan observasi yang telah dilakukan, sebagian besar siswa mengalami kejenuhan dalam belajar karena dalam kegiatan pembelajaran guru masih menggunakan metode mengajar konvensional yaitu ceramah. Selain itu sumber belajar siswa hanya berasal dari guru dan buku paket saja tanpa adanya penggunaan media pembelajaran. Hal tersebut mengakibatkan siswa tidak memperhatikan penjelasan guru dan siswa kurang memahami materi yang diajarkan. Sehingga perlu cara baru untuk menyampaikan materi ajar dalam sistem yang mandiri maupun terstruktur. Oleh karena itu, perlu suatu pengembangan media pembelajaran yang lebih inovatif, efektif, dan efisien.

b. Analisis Standar Kompetensi (SK) dan Kompetensi Dasar (KD)

Standar Kompetensi yang akan dimuat adalah Memahami Daur Hidup Beragam Jenis
Makhluk Hidup dengan Kompetensi Dasar Mendeskripsikan Daur Hidup Beberapa Hewan Di Lingkungan Sekitar, Misalnya Kecoa, Nyamuk, Kupu-Kupu, Kucing. Kompetensi Dasar dijabarkan menjadi 5 indikator yaitu menjelaskan pengertian daur hidup, menjelaskan daur hidup kecoa, menjelaskan daur hidup nyamuk, menjelaskan daur hidup kupu-kupu, dan menjelaskan daur hidup kucing.

\section{Tahap Desain (design)}

Berdasarkan hasil analisis, tahap yang selanjutnya dilakukan adalah tahap desain atau perancangan produk yang akan dikembangkan. Perancangan desain produk yang meliputi pembuatan storyboard yang berfungsi sebagai panduan seperti peta untuk memudahkan proses pembuatan media, menetapkan materi, penyusunan soal dan jawaban kemudian mengkaji mata pelajaran sesuai dengan kurikulum. Standar Kompetensi Memahami Daur Hidup Beragam Jenis Makhluk Hidup dengan Kompetensi Dasar Mendeskripsikan Daur Hidup Beberapa Hewan Di Lingkungan Sekitar dikaji sesuai dengan panduan kurikulum yang berlaku di sekolah yaitu KTSP (Kurikulum Tingkat Satuan Pendidikan).

\section{Tahap Pengembangan (Development)}

a. Membuat Produk Media Pembelajaran.

Produk media berupa CD Interaktif menggunakan Aplikasi Adobe Flash Profesional CS6, format multimedia pembelajaran model tutorial. Berikut ini hasil dari pembuatan media Multimedia Interaktif Daur Hidup Hewan

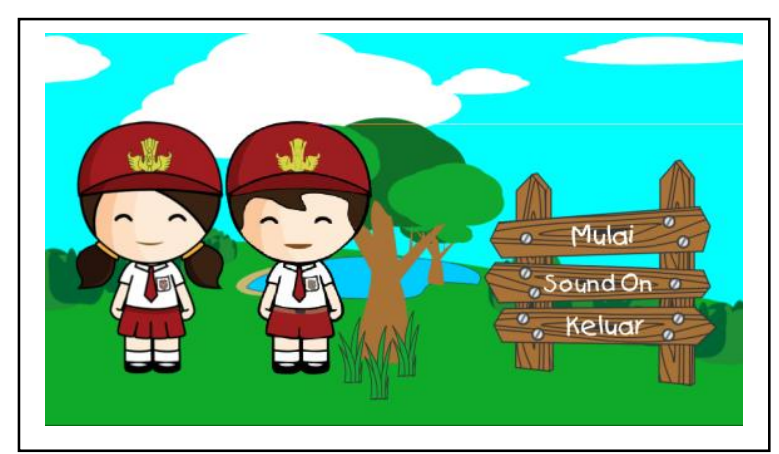

Gambar 3.1. Hasil Aplikasi Multimedia Interaktif Daur Hidup Hewan 


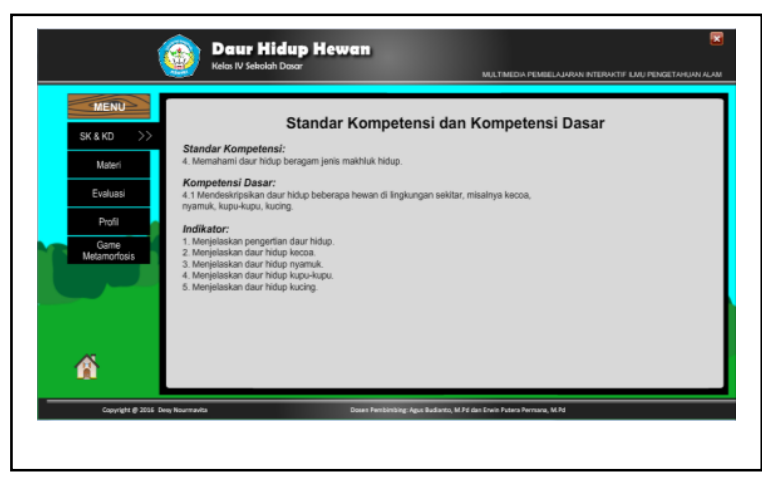

Gambar 3.2

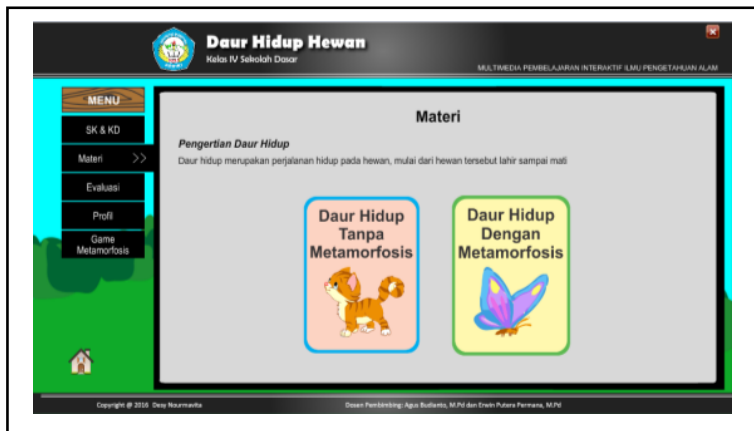

Gambar 3.3
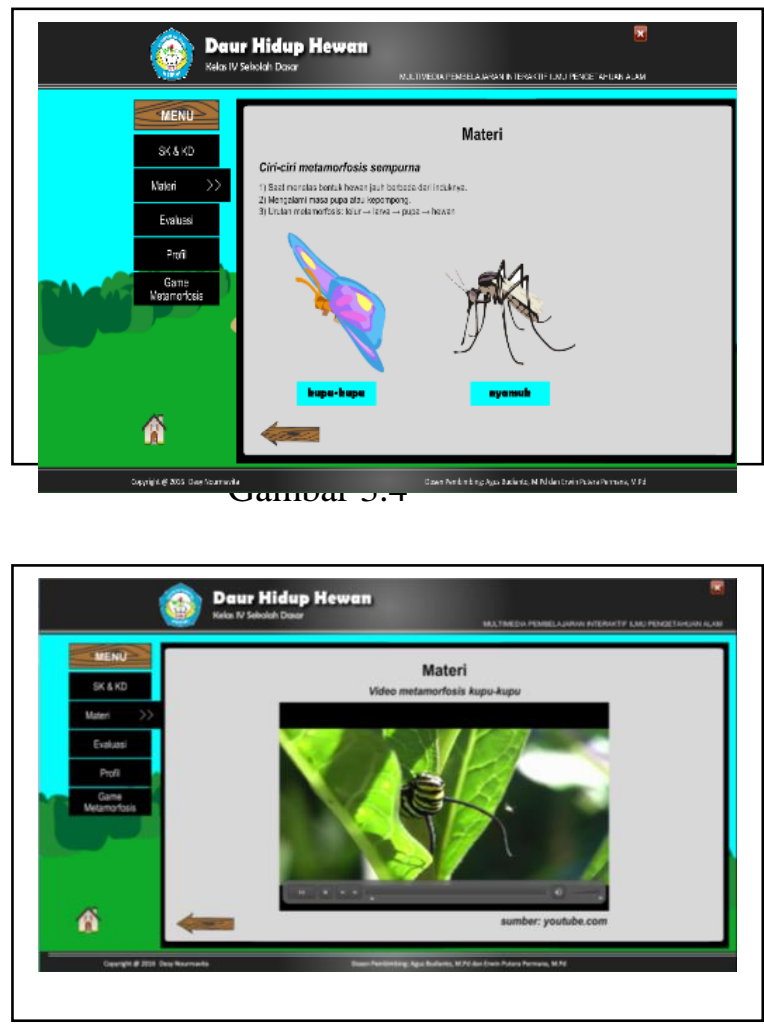

Gambar 3.5

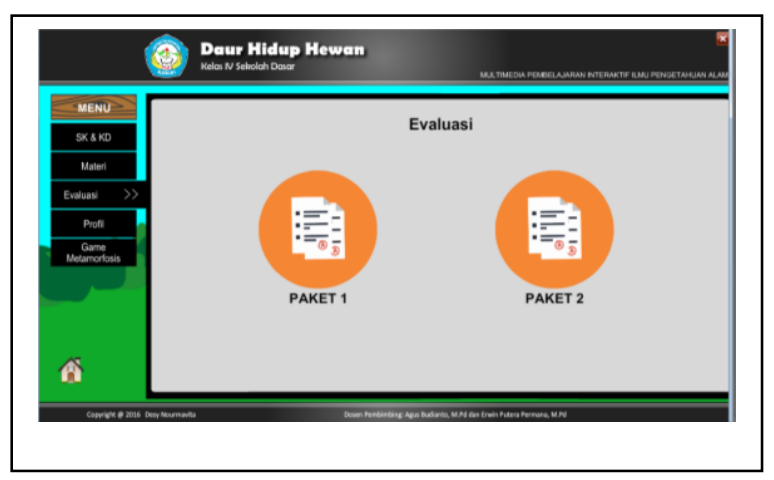

Gambar 3.6

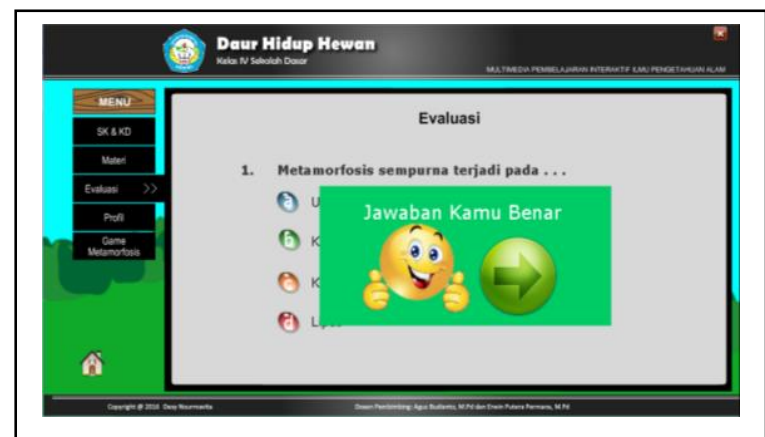

Gambar 3.7

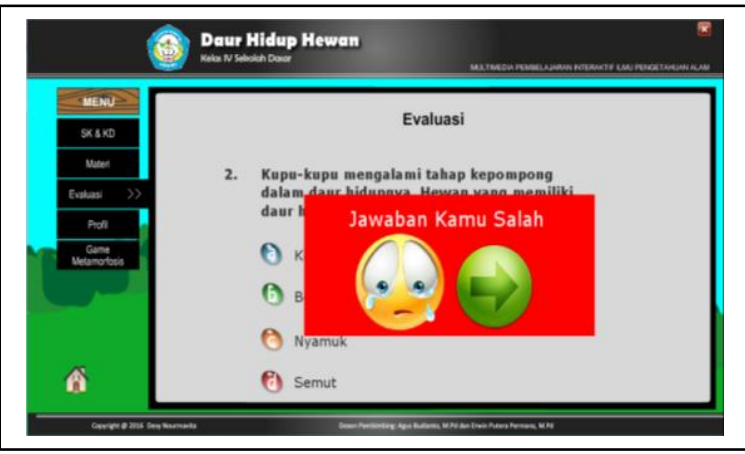

Gambar 3.8

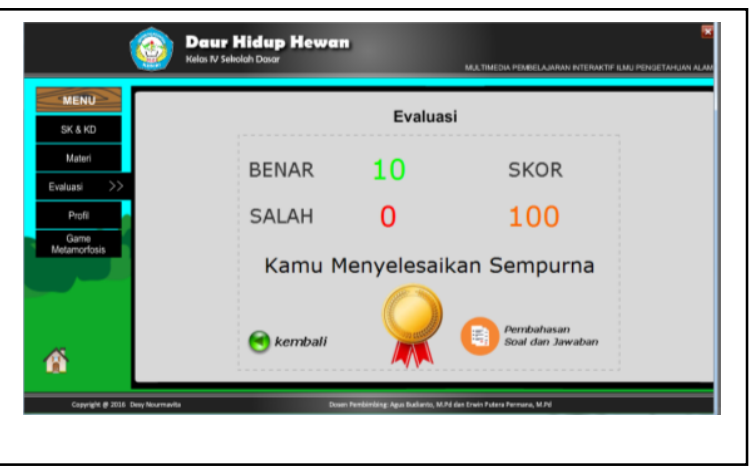

Gambar 3.9 


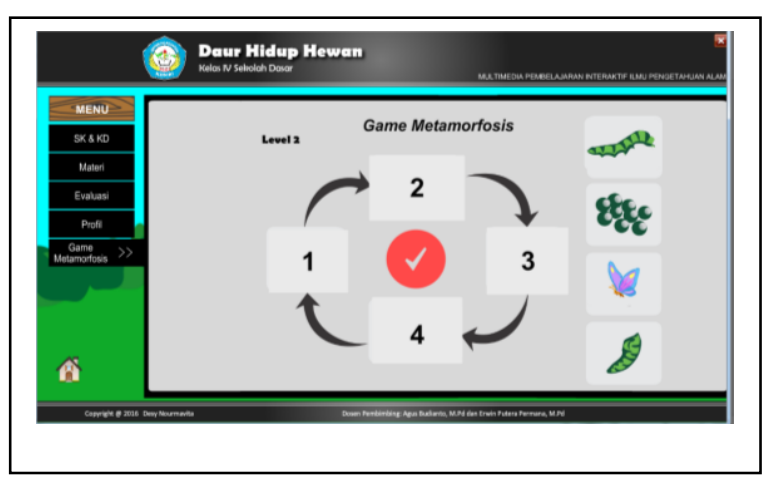

Gambar 3.10

b. Validasi

Penilaian kelayakan media pembelajaran Multimedia Interaktif Daur Hidup Hewan oleh ahli materi, ahli media, dan praktisi pembelajaran IPA.

Tabel 1. Penilaian Media oleh Ahli Materi

\begin{tabular}{|c|c|c|c|c|c|}
\hline Aspek & JI & Skor & $\begin{array}{c}\text { Krite } \\
\text { ria }\end{array}$ & $(\%)$ & $\begin{array}{c}\text { Krite } \\
\text { ria }\end{array}$ \\
\hline $\begin{array}{l}\text { Relevansi } \\
\text { Materi }\end{array}$ & 4 & 14 & SB & 87,5 & SL \\
\hline $\begin{array}{l}\text { Pengorga } \\
\text { nisasian } \\
\text { Materi }\end{array}$ & 6 & 20 & SB & 66,7 & $\mathrm{~L}$ \\
\hline Evaluasi & 5 & 20 & SB & 100 & SL \\
\hline Bahasa & 2 & 8 & SB & 100 & SL \\
\hline $\begin{array}{l}\text { Strategi } \\
\text { Pembelaj } \\
\text { aran }\end{array}$ & 5 & 17 & SB & 85 & SL \\
\hline $\begin{array}{l}\text { Skor } \\
\text { Total }\end{array}$ & 22 & 79 & SB & 89,8 & SL \\
\hline
\end{tabular}

Tabel 2. Penilaian Media oleh Ahli Media

\begin{tabular}{lccccc}
\hline \multicolumn{1}{c}{ Aspek } & JI & Skor & $\begin{array}{c}\text { Krite } \\
\text { ria }\end{array}$ & $\begin{array}{c}\text { (\%) } \\
\text { Krite } \\
\text { ria }\end{array}$ \\
\hline Bahasa & 2 & 8 & SB & 100 & SL \\
\hline $\begin{array}{l}\text { Strategi } \\
\text { Pembelajar } \\
\text { an }\end{array}$ & 5 & 19 & SB & 95 & SL \\
\hline $\begin{array}{l}\text { Rekayasa } \\
\text { Perangkat } \\
\text { Lunak }\end{array}$ & 4 & 15 & SB & 93,7 & SL \\
\hline $\begin{array}{l}\text { Tampilan } \\
\text { Visual }\end{array}$ & 9 & 30 & SB & 83 & SL \\
\hline $\begin{array}{l}\text { Kesesuaian } \\
\text { Multimedia } \\
\text { Model } \\
\text { Tutorial }\end{array}$ & 7 & 27 & SB & 96,4 & SL \\
\hline Skor Total & 27 & 99 & SB & 91,6 & SL \\
\hline
\end{tabular}

Tabel 3. Penilaian Media oleh Ahli Praktisi Pembelajaran SDN Krecek 3

\begin{tabular}{|c|c|c|c|c|c|}
\hline Aspek & JI & Skor & $\begin{array}{c}\text { Krite } \\
\text { ria }\end{array}$ & $(\%)$ & $\begin{array}{c}\text { Krite } \\
\text { ria }\end{array}$ \\
\hline $\begin{array}{l}\text { Relevansi } \\
\text { Materi }\end{array}$ & 5 & 20 & SB & 100 & SL \\
\hline $\begin{array}{l}\text { Pengorgani } \\
\text { sasian } \\
\text { Materi }\end{array}$ & 15 & 58 & SB & 96,7 & SL \\
\hline Bahasa & 2 & 8 & SB & 100 & SL \\
\hline $\begin{array}{l}\text { Strategi } \\
\text { Pembelajar } \\
\text { an }\end{array}$ & 5 & 19 & SB & 95 & SL \\
\hline $\begin{array}{l}\text { Perangkat } \\
\text { Lunak }\end{array}$ & 2 & 8 & SB & 100 & SL \\
\hline $\begin{array}{l}\text { Tampilan } \\
\text { Visual }\end{array}$ & 2 & 6 & B & 75 & $\mathrm{~L}$ \\
\hline Skor Total & 31 & 119 & SB & 95,9 & SL \\
\hline \multicolumn{6}{|c|}{$\begin{array}{l}\text { Tabel 4. Penilaian Media oleh Ahli Praktisi } \\
\text { Pembelajaran SD Negeri Tunglur }\end{array}$} \\
\hline Aspek & J & Skor & $\begin{array}{l}\text { Kriteri } \\
\text { a }\end{array}$ & $(\%)$ & $\begin{array}{l}\text { Kriteri } \\
\quad \mathbf{a}\end{array}$ \\
\hline $\begin{array}{l}\text { Relevansi } \\
\text { Materi }\end{array}$ & 5 & 20 & SB & 100 & SL \\
\hline $\begin{array}{l}\text { Pengorga } \\
\text { nisasian } \\
\text { Materi }\end{array}$ & $\begin{array}{l}1 \\
5\end{array}$ & & SB & 98,3 & SL \\
\hline Bahasa & 2 & 8 & SB & 100 & SL \\
\hline $\begin{array}{l}\text { Strategi } \\
\text { Pembelaja } \\
\text { ran }\end{array}$ & 5 & 20 & SB & 100 & SL \\
\hline $\begin{array}{l}\text { Perangkat } \\
\text { Lunak }\end{array}$ & 2 & 8 & SB & 100 & SL \\
\hline $\begin{array}{l}\text { Tampilan } \\
\text { Visual }\end{array}$ & 2 & 7 & SB & 87,5 & SL \\
\hline Skor Total & $\begin{array}{l}3 \\
1\end{array}$ & 119 & SB & 95,9 & SL \\
\hline
\end{tabular}

Keterangan :

JI : Jumlah Indikator

SB : Sangat Baik

SL : Sangat Layak

L : : Layak

$\% \quad$ : Persentase

c. Revisi

Melakukan revisi terhadap media pembelajaran Multimedia Interaktif Daur Hidup Hewan berdasarkan masukan dan saran dari ahli materi, ahli media, dan praktisi pembelajaran.

\section{Tahap Implementasi}

Tahap implementasi ini, produk akan diuji cobakan kepada 20 peserta didik dari SDN Krecek 3 dan 30 peserta didik dari SD Negeri Tunglur. Pada tahap ini juga dibagikan angket untuk mengukur dan mengetahui pendapat atau 
respon peserta didik mengenai media pembelajaran berupa $C D$ Interaktif untuk pembelajaran Ilmu Pengetahuan Alam (IPA) materi daur hidup beberapa hewan di lingkungan sekitar.

Tabel 5. Rekapitulasi Pendapat Siswa

\begin{tabular}{|c|c|c|c|c|c|}
\hline \multirow[t]{2}{*}{ No } & \multirow[t]{2}{*}{ Indikator } & \multicolumn{2}{|c|}{$\begin{array}{l}\text { Jawab } \\
\text { an }\end{array}$} & \multirow[t]{2}{*}{$\mathbf{n}$} & \multirow{2}{*}{$\begin{array}{r}\text { Prese } \\
\text { ntasi } \\
\text { Jawab } \\
\text { an Ya }\end{array}$} \\
\hline & & $\mathbf{Y}$ & $\mathbf{T}$ & & \\
\hline 1 & $\begin{array}{l}\text { Kemenarikan } \\
\text { penyampaian } \\
\text { materi }\end{array}$ & 50 & 0 & 50 & $100 \%$ \\
\hline 2 & $\begin{array}{l}\text { Kejelasan contoh } \\
\text { soal yang diberikan }\end{array}$ & 48 & 2 & 50 & $96 \%$ \\
\hline 3 & $\begin{array}{l}\text { Kejelasan rumusan } \\
\text { soal }\end{array}$ & 47 & 3 & 50 & $94 \%$ \\
\hline 4 & $\begin{array}{l}\text { Kemampuan } \\
\text { mendorong rasa } \\
\text { ingin tahu siswa }\end{array}$ & 44 & 6 & 50 & $88 \%$ \\
\hline 5 & $\begin{array}{l}\text { Kemampuan media } \\
\text { dalam } \\
\text { meningkatkan } \\
\text { pemahaman siswa }\end{array}$ & 49 & 1 & 50 & $98 \%$ \\
\hline 6 & $\begin{array}{l}\text { Kemampuan media } \\
\text { dalam menambah } \\
\text { motivasi belajar } \\
\text { siswa }\end{array}$ & 48 & 2 & 50 & $96 \%$ \\
\hline
\end{tabular}

\section{SIMPULAN}

Setelah melakukan validasi ahli, validasi praktisi dan penelitian di dua sekolah, yaitu SDN Krecek 3 dan SD Negeri Tunglur khususnya pada siswa kelas IV, maka memperoleh data sebagaimana yang telah diuraikan pada Bab IV. Setelah melakukan penelitian, data hasil penelitian kemudian dianalisis, sehingga dari analisis data tersebut dapat disimpulkan hasilnya sebagai berikut:

1. Pengembangan Multimedia Interaktif Daur Hidup Hewan menggunakan aplikasi adobe flash professional CS6, format multimedia pembelajaran model tutorial, dengan prosedur pengembangan model ADDIE yaitu Analysis (Analisis), Development (Desain), Implementation (Implementasi), Evaluation (Evaluasi).

2. Respon guru terhadap media ini mendapatkan rasa optimisme guru untuk mencapai tujuan pembelajaran. Analisis terhadap respon guru didapat sejak uji coba draf media hingga validasi media. Guru yang terlibat memberi respon yang positif terhadap penggunaan media. Sedangkan respon dari siswa terhadap media ini mendapatkan respon positif, hal ini terlihat dari pelaksanaan pembelajaran yang berlangsung dengan sikap siswa yang aktif serta hasil dari angket yang telah dibagikan kepada siswa. Hasil rekapitulasi pendapat siswa mengenai media dapat dilihat pada tabel 4.3, dimana memperoleh rata-rata persentase jawaban Ya adalah 97\% sehingga dapat dikatakan bahwa siswa sangat menyukai media ini.

3. Kelayakan Multimedia Interaktif Daur Hidup Hewan berdasarkan penilaian ahli materi secara keseluruhan aspek mendapatkan persentase $89,7 \%$, penilaian ahli media $91,6 \%$, penilain ahli praktisi I $95,97 \%$, dan penilaian ahli praktisi II 98,4\%. Hal ini menunjukkan bahwa media dari aspek keseluruhan berdasarkan persentase penilaian kelayakan berada pada kategori sangat layak dijadikan media pembelajaran Ilmu Pengetahuan Alam untuk siswa kelas IV SD.

\section{DAFTAR PUSTAKA}

Haryono. 2013. Pembelajaran IPA yang Menarik dan Mengasyikan:Teori dan Aplikasi PAIKEM. Yogyakarta : Kepel Press

Mulyatiningsih, Endang. 2011. Riset Terapan Bidang Pendidikan \& Teknik. Yogyakarta : UNY Press Sugiyono. 2012. Metode Penelitian Kuantitatif Kualitatif dan $R \& D$. Bandung : Alfabeta.

Susanto, Ahmad. 2013. Teori Belajar \& Pembelajaran di Sekolah Dasar. Jakarta : Prenadamedia Group 